\title{
Intercropping Promote Sustainable Agriculture and Clean Enviroment
}

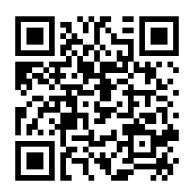

\author{
Jamal Nasar*1 and Ashfaq Alam² \\ ${ }^{1}$ College of Resource and Environmental Science, Jilin Agricultural University, China \\ ${ }^{2}$ The university of Agriculture Peshawar, Khyber Pukhton Khwa, Pakistan
}

Received: April 26, 2018; Published: May 01, 2018

*Corresponding author: Jamal Nasar, A PhD student at College of Resources and Environmental Sciences Jilin Agricultural University Changchun, PR China

\section{Opinion}

The increasing world population which threaten the human food demand. To satisfy the world food demand a focus must need to agriculture land which decreasing day by day due to increasing population. In this competetive world people are in race to buy lands to build factories and buildings which destroy our agriculture land and increase environmental pollution which further effect the life on earth. To solve all these issues we must think about new agriculture ideas to protect our agriculture and environment. Here are some opinions which can be adopted to the best for future safety.Intercropping growing of two or more crops simultaneously on the same field is called intercropping or cropping mixture. intercropping actually is an old agriculture practice since the farming began. Unfortunately equipment farming modernization has changed our farming practices into what they are today, which is mostly sole-cropping or mono-cropping.Solecropping is the cropping of single crop for short period of time with the intention of promoting high yielding varities of crops you could plant on one field. It is obvious that such kind of crops varities need high chemical fertilizers, where fertilizers companies in race to manufacture high chemical fertilizers for high production with high price which our local farmers happily purchase in the market. But no one knows that these have negative effects to our environment and somewhat to soil ecosystem for example water pollution where the nitrate from soil goes to ground water, gas emission to air, soil acidification, nitrogen loss during growing season which is key component for crop, excessive $\mathrm{N}$ often combine with summer rains, soil degredation, soil biodiversity with the use of chemical fertilizers which effect the cropping system also adversly effect animals life on earth. All these activities promting for the increasing world population food security.

Under such circumstances, we must adjust the structure of agricultural industry. Based on actual production under local conditions, we need to establish a crops and pastures planting patteren like intercropping to ensure world food security, environmental protection, promote agriculture, improve farmers economic income. We suggest that cereal-legumes intercropping is the best intercropping which can efficiently utilize solar and soil resources with minimum fertilizers inputs and a best option high quality production and agriculture development. The challenge here is to connect the mentalities of the farmers boost their work method. To do so we must spread our knowledge about intercropping in every corner of the world about intercropping and its advantages. It is necessary to make agriculture teams to visit farmers and educate them about intercropping and to encourage them not to use high chemical fertilizers. In way we can save agriculture land, increase agriculture production, clean our environment and save life on earth.
CC This work is licensed under Creative Submission Link: https://biomedres.us/submit-manuscript.php

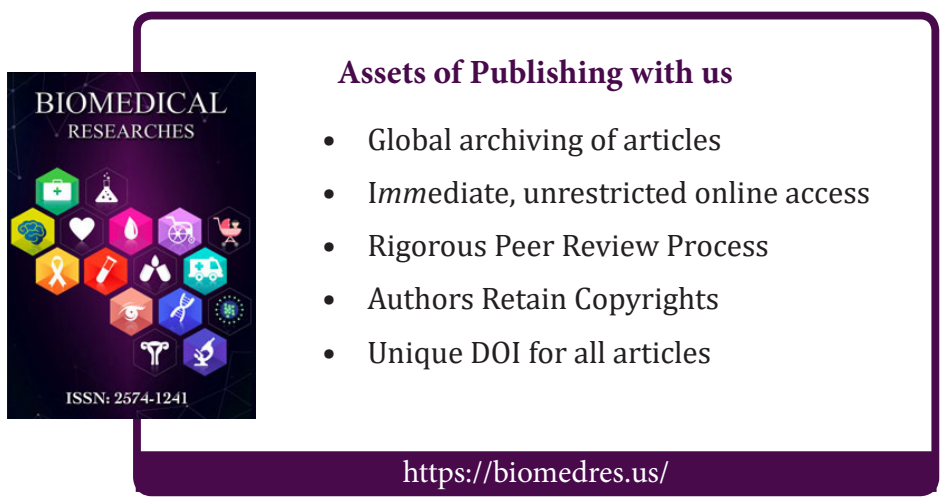

